\title{
Investigating the effects of regional characteristics on the spatial distribution of COVID-19 pandemic: a case of Turkey
}

\author{
Cem Kırlangıçoğlu' ${ }^{1}$
}

Received: 8 February 2021 / Accepted: 9 February 2022 / Published online: 22 February 2022

(c) Saudi Society for Geosciences 2022

\begin{abstract}
Today, the COVID-19 pandemic continues to threaten all humanity worldwide. Turkey, one of the countries severely affected by the disease, has 81 provinces showing regionally different incidence rate patterns. This study explores the effect of social, economic, demographic, climatic, and geographic characteristics of different regions on the COVID-19 spread in Turkey. Geographic Information System (GIS)-based spatial interpolation techniques and multiple linear regression analysis have been conducted to examine the relationship between provincial incidence rates and eighteen explanatory variables determined by an in-depth literature survey. Results show that five of eighteen predictors have a statistically significant impact and can explain 57\% of the regional variability of the COVID-19 incidence rates. Urbanization level, education index, and wind speed positively associate with the virus spread, but the sunshine duration and average temperature negatively correlate. On the other hand, $43 \%$ of the variation is due to other factors not included in this study. Therefore, an interdisciplinary study should be carried out by participating in all the related fields such as natural sciences, engineering and technology, medical and health sciences, social sciences, and humanities to understand the dynamics of the disease.
\end{abstract}

Keywords COVID-19 · GIS · Regression analysis · Turkey

\section{Introduction}

After the first case in China in December 2019, COVID-19 pandemic now threatens all humanity. Currently, there are $393,502,787$ confirmed cases and 5,735,289 deaths on the global scale (JHU 2022). Until now, many scientific studies have been carried out, and a vast amount of scientific articles has been published worldwide to understand the effects of social, demographic, economic, physical, biological, geographic, and environmental factors on COVID-19 incidence rates. The literature survey proffers that few researchers have addressed the issue of principal reasons of the virus spread in Turkey. In addition, previous works have been limited to specific parts of the problem. This study investigates the relationship between possible causes and COVID-19 incidence rates in Turkey with a comprehensive and holistic

\section{Responsible Editor: Biswajeet Pradhan}

Cem Kırlangıçoğlu

kirlangicoglu@sakarya.edu.tr

1 Faculty of Art, Design and Architecture, Sakarya University, Sakarya, Turkey approach by Geographic Information System (GIS)-based spatial modeling techniques and advanced statistics.

Hays (2009) claims that physically inadequate living spaces and environments played an essential role in spreading epidemic and pandemic diseases throughout history and the spread of diseases to enormous masses occurred because of people living together more intensely in line with the development of urbanization. Alirol et al. (2011) state highdensity cities as the breeding ground for pandemics. People live together in cities, come together in public spaces, use public transportation, and consciously or unconsciously violate the social distance necessary to protect themselves. An increasing number of studies have found that population density has a strong positive correlation with the COVID-19 spread (Sarkar et al. 2021; Arif and Sengupta 2021; Coşkun et al. 2021; Mehmood et al. 2021; Mishra et al. 2020; Mansour et al. 2021; Hamidi et al. 2020; Almagro and OraneHutchinson 2020; Rocklöv and Sjödin 2020; Wheaton and Thompson 2020). More recent evidence reveals that transmission of the virus increases with the social and spatial interaction between people, so urbanized areas are favorable environments for the spread of outbreaks because of their building and population density. Conversely, Carozzi 
et al. (2020) have found no association between population density and COVID-19 incidence rates in urban counties of the USA. On the other hand, Bhadra et al. (2021) have found a moderate association between population density and COVID-19 spread in India through deep regression and correlation analyses based on case numbers and mortality rates. Gavi (2020) argues that urbanization rate and climate change are effective on the virus spread, too. Since COVID19 is an airborne disease, meteorological conditions such as daily sunshine duration, temperature, wind, humidity, and air quality may influence the spread of the virus (Iqbal et al. 2020; Qi et al. 2020; Xie and Zhu 2020; Wu et al. 2020). Gupta et al. (2020), Xie and Zhu (2020), Tosepu et al. (2020), Bashir et al. (2020), Chen et al. (2020), and Şahin (2020) affirm that there is a linear correlation with average air temperature and COVID-19 cases in different countries such as India, Indonesia, Turkey, and the USA. Humidity is accepted as another influential factor in virus spread by some researchers, such as Ahmadi et al. (2020), Ali and Alharbi (2020), Auler et al. (2020), and Wu et al. (2020). Thangariyal et al. (2020) point out a negative and substantial correlation between daily sunshine duration and COVID-19 cases after examining 138 countries worldwide. In addition, Zhu et al. (2020), Frontera et al. (2020), and Wang et al. (2020) consider that the wind has an indirect effect on virus spread by affecting air quality. Alternatively, Coşkun et al. (2021) report the direct effect of wind speed on virus spread by increasing air circulation in Turkey. Correspondingly, air quality may be another comprehensive indicator of the spread of many airborne viruses like COVID-19 (Zhang et al. 2020a). Firstly, where air pollution is high, the virus can stay in the air longer, travel further distances, spread over larger areas, and penetrate deeper into the lungs (Andree 2020; Zhu et al. 2020; Doremalen et al. 2020). Secondly, air pollution may negatively affect the normal functions of the lungs and make some people more vulnerable than others to the virus (Ali and Alharbi 2020; Korber 2020; Helen 2020; Fattorini and Regoli 2020). Saadat et al. (2020) found that different socioeconomic groups react differently to the virus spread, especially that household size may positively affect the incident rates. The householdbased studies highlight the virus's secondary attack rate for household contacts, which is much higher than that for nonhousehold close contacts (Jing et al. 2020). That means if infected people are not isolated, the disease risk increases for their household. In their overview, Zhang et al. (2021) underline that cities with higher GDP values are more at risk than others because of the virus spread due to higher trade and commercial activities among people. Likewise, Zhang et al. (2020b) investigated a robust positive correlation between case numbers and GDP in Chinese cities. Mansour et al. (2021) explored sociodemographic and health factors such as age structure, population density, hospital beds, and nursing practitioners to explain and predict the spatial transmission of the incidence rates in Oman. They maintain that the incidence rate increases as parallel to an increase in age, especially that people older than 65 years are more at risk than the others. Age may be a crucial factor for the incident rates because younger and older people have different susceptibility levels. Reniers (2020) outlines several reasons that young people take more risks against social distancing and other precautions. Zhang et al. (2021) draw our attention to the inverse correlation between the health indicators such as the number of health institutions, health personnel, hospital beds, and the case numbers after examining 342 cities of China. In their review, Sands et al. (2016) affirm that health infrastructure, health surveillance, and response measures directly affect any virus spread; thus, each province's physician number and hospital bed capacity are crucial factors to fight against these types of viruses. In a study conducted in Oman, COVID-19 incidence rates have been found to be negatively associated with hospital bed numbers (Mansour et al. 2021).

Understanding the principal variables and the main characteristics of the virus will help us propose a new way of urbanism for post-pandemic cities (Megahed and Ghoneim 2020). There may be hundreds of factors affecting the virus spread in different regions under divergent physical and social conditions. In line with the official data available, this study focuses on eighteen possibly explanatory variables, which are population density, urbanization level, median age, household size, GDP per capita, average air temperature, humidity, daily sunshine duration, average wind speed, air quality index, health index, income and wealth index, education index, environment index, social life index, life satisfaction ratio, number of hospital beds, and total physician number in the cities.

\section{Area of the study}

The study area, Turkey, is mathematically positioned between approximately $26^{\circ}-45^{\circ}$ eastern meridians and $36^{\circ}-42^{\circ}$ northern parallels given in Fig. 1 (Doğanay and Orhan 2019). The population of Turkey is reported as $83,614,362$ by the Turkish Statistical Institute (Turkstat 2020), and the total surface area is $777,971 \mathrm{~km}^{2}$. According to the Turkish Republic Ministry of Environment and Urbanization (MoEU 2011), 97\% of the country is in Asia, and the rest is in Europe. Database of Coordination of Information on the Environment (CORINE), a prototype project working on many different environmental issues, is serviced by the Ministry of Agriculture and Forestry in Turkey (MoAF 2019). It shows that $1.94 \%$ of the country is an artificial area, $42.26 \%$ is an agricultural area, $50.31 \%$ is forest and seminatural area, $0.51 \%$ is wetland, and $4.98 \%$ is water body. 


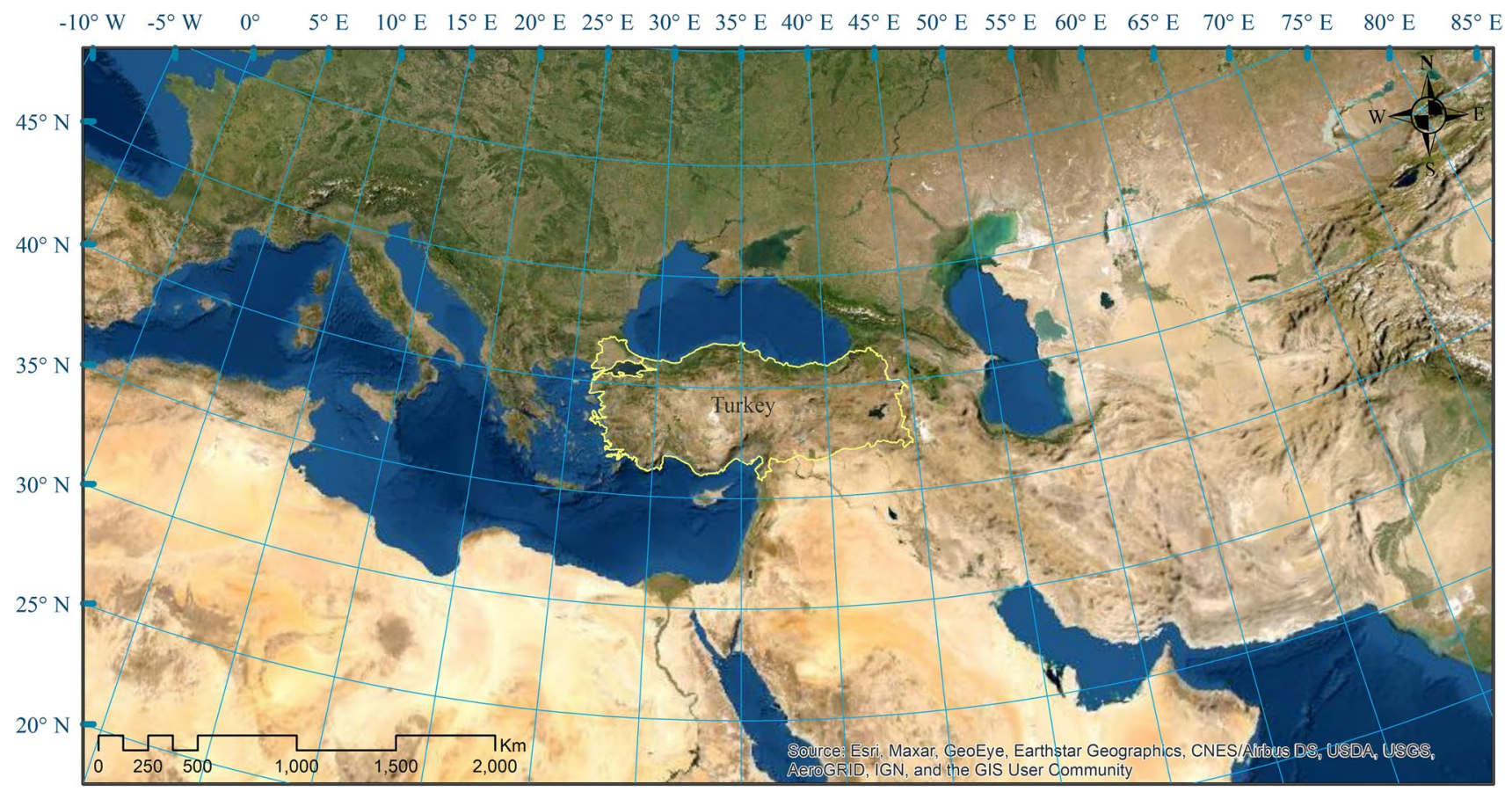

Fig. 1 Location of the study area (Turkey)

In Turkey, the first COVID-19 case was notified on March 11,2020 . As of July 9, 2021, the confirmed total case number is 5,514,373 and the death number is 50,450, as maintained by the Republic of Turkey Ministry of Health $(\mathrm{MoH}$ 2021). This paper will focus on 81 provinces of Turkey to determine the influential factors and reasons for regional differences in confirmed incidence rates.

\section{Data and method}

The Republic of Turkey Ministry of Health releases weekly situation reports about COVID-19 statistics, including provincial incidence rates and case numbers since February 8 , 2021. This study has been conducted by 5 months of provincial data published until July 9, 2021. Table 1 enumerates the COVID-19 numbers for each province based on the official data published between February 8, 2021, and July 9, 2021.

Statistical studies are usually carried out on numbers, but numbers visualized on maps are much more effective for understanding the spatial distribution of statistics. So, inverse distance weighted (IDW) interpolation tool of ArcGIS, a commercially available software package, has been used to produce spatial distribution maps related to all the variables. The dataset is based on point data of 81 city centers, including spatial and non-spatial data about the provinces, acquired from Turkey's Ministry of Environment and
Urban Planning. Figure 2 illustrates the distribution of confirmed case numbers in Turkey.

İstanbul has 924,793 cases, the highest COVID-19 case number among Turkish cities. Ankara, İzmir, and Konya provinces follow it. A distribution map of case numbers is not enough to understand the reasons and regional differences of the virus spread. While the population of İstanbul is 15,519.267, the population of Tunceli Province is just 84,660 (Turkstat 2020). Naturally, the case counts are much higher in Istanbul, which has a 183 times greater population size. For this reason, the case distribution has been normalized for all provinces. Figure 3 depicts the spatial distribution of confirmed COVID-19 incidence rates (case number per 100,000 people) in Turkey.

Figure 3 demonstrates that the Marmara, Mid-Black Sea, and Eastern Black Sea regions have the highest incidence rates while Southeast Anatolia and the south part of Eastern Anatolia regions have the lowest rates. As the figures reveal the regional differences, this study will use correlation and regression analyses to determine the reasons and the association between possible factors and COVID-19 incidence rates. While correlation is a model that defines the relationship between two or more variables through their covariance (Demir 2019), a regression model gives the relationship's mathematical function among variables. That function may estimate the value of a variable based on other variables. Regression analysis explains a variation on the dependent variable $(Y)$ with independent variables $\left(X_{1}, X_{2}, X_{3}, \ldots, X_{n}\right)$. The dependent variable is 
Table 1 Confirmed COVID-19 case numbers and incidence rates for 81 provinces of Turkey

\begin{tabular}{|c|c|c|}
\hline Province & Case no & Incidence rate \\
\hline İstanbul & 924,793 & 5959 \\
\hline Ankara & 215,582 & 3823 \\
\hline İzmir & 110,710 & 2535 \\
\hline Konya & 99,385 & 4452 \\
\hline Bursa & 98,988 & 3239 \\
\hline Kocaeli & 90,543 & 4636 \\
\hline Samsun & 79,159 & 5870 \\
\hline Antalya & 61,712 & 2457 \\
\hline Kayseri & 56,845 & 4039 \\
\hline Balıkesir & 54,133 & 4406 \\
\hline Tekirdağ & 50,333 & 4769 \\
\hline Gaziantep & 43,788 & 2116 \\
\hline Ordu & 38,766 & 5140 \\
\hline Eskişehir & 36,750 & 4141 \\
\hline Sakarya & 34,359 & 3337 \\
\hline Mersin & 34,140 & 1855 \\
\hline Trabzon & 33,847 & 4184 \\
\hline Manisa & 30,613 & 2125 \\
\hline Adana & 30,324 & 1355 \\
\hline Malatya & 30,222 & 3777 \\
\hline Erzurum & 28,654 & 3760 \\
\hline Çanakkale & 28,371 & 5233 \\
\hline Tokat & 26,973 & 4402 \\
\hline Hatay & 24,955 & 1532 \\
\hline Giresun & 24,918 & 5557 \\
\hline Diyarbakır & 22,797 & 1298 \\
\hline Zonguldak & 20,367 & 3417 \\
\hline Kütahya & 20,094 & 3469 \\
\hline Aydın & 19,742 & 1777 \\
\hline Muğla & 19,653 & 1999 \\
\hline Kırklareli & 18,949 & 5237 \\
\hline Denizli & 18,846 & 1817 \\
\hline Çorum & 18,623 & 3508 \\
\hline Afyonkarahisar & 18,573 & 2546 \\
\hline Sivas & 18,485 & 2893 \\
\hline Şanlıurfa & 18,414 & 888 \\
\hline K. Maraş & 18,246 & 1581 \\
\hline Kastamonu & 17,305 & 4561 \\
\hline Edirne & 16,660 & 4025 \\
\hline Rize & 16,337 & 4760 \\
\hline Ağr1 & 16,102 & 3003 \\
\hline Osmaniye & 15,613 & 2898 \\
\hline Adiyaman & 14,684 & 2344 \\
\hline Düzce & 13,534 & 3451 \\
\hline Aksaray & 13,532 & 3250 \\
\hline Yalova & 13,370 & 4934 \\
\hline Elâzı̆̆ & 13,235 & 2239 \\
\hline Van & 12,857 & 1131 \\
\hline Yozgat & 12,804 & 3040 \\
\hline
\end{tabular}

Table 1 (continued)

\begin{tabular}{|c|c|c|}
\hline Province & Case no & Incidence rate \\
\hline Amasya & 12,664 & 3749 \\
\hline Isparta & 12,453 & 2799 \\
\hline Bolu & 11,858 & 3751 \\
\hline Niğde & 10,871 & 2996 \\
\hline Erzincan & 9282 & 3954 \\
\hline Nevşehir & 9021 & 2977 \\
\hline Kırıkkale & 8986 & 3175 \\
\hline Sinop & 8747 & 4008 \\
\hline Bilecik & 8362 & 3811 \\
\hline Mardin & 7994 & 953 \\
\hline Batman & 7900 & 1298 \\
\hline Kars & 7255 & 2542 \\
\hline Karaman & 6877 & 2715 \\
\hline Karabük & 6572 & 2645 \\
\hline Bartın & 6423 & 3240 \\
\hline Burdur & 6239 & 2304 \\
\hline Bitlis & 6141 & 1764 \\
\hline Kirşehir & 6137 & 2526 \\
\hline Çankırı & 6089 & 3110 \\
\hline Uşak & 5676 & 1532 \\
\hline Gümüşhane & 5066 & 3079 \\
\hline Kilis & 5061 & 3552 \\
\hline Bingöl & 5053 & 1806 \\
\hline Muş & 5045 & 1234 \\
\hline Iğdır & 4645 & 2329 \\
\hline Siirt & 4178 & 1265 \\
\hline Artvin & 4033 & 2360 \\
\hline Hakkâri & 3147 & 1120 \\
\hline Bayburt & 2921 & 3443 \\
\hline Şırnak & 2759 & 521 \\
\hline Ardahan & 2595 & 2667 \\
\hline Tunceli & 1694 & 2001 \\
\hline
\end{tabular}

explained or predicted in the regression model (Ersöz and Ersöz 2019). This variable is assumed to be associated with the independent variables, also called explanatory variables in the regression model (Karataş 2014). The linear equation between $Y_{i}$ and $X_{i}$ variables is obtained as follows:

$Y_{i}=\beta_{0}+\beta_{1} X_{i 1}+\beta_{2} X_{i 2}+\beta_{3} X_{i 3}+\ldots \beta_{n} X_{i n}+\epsilon_{i}^{-}$

where $Y$ is the expected value of the dependent variable, $X$ is the independent variable, $\beta$ is the regression coefficient, $\varepsilon$ is the residual, and $n$ is the number of independent variables.

Table 2 lists the variables used in this study in line with the literature survey and available official data.

The data about all the variables have been ensured from the local and central government agencies. 


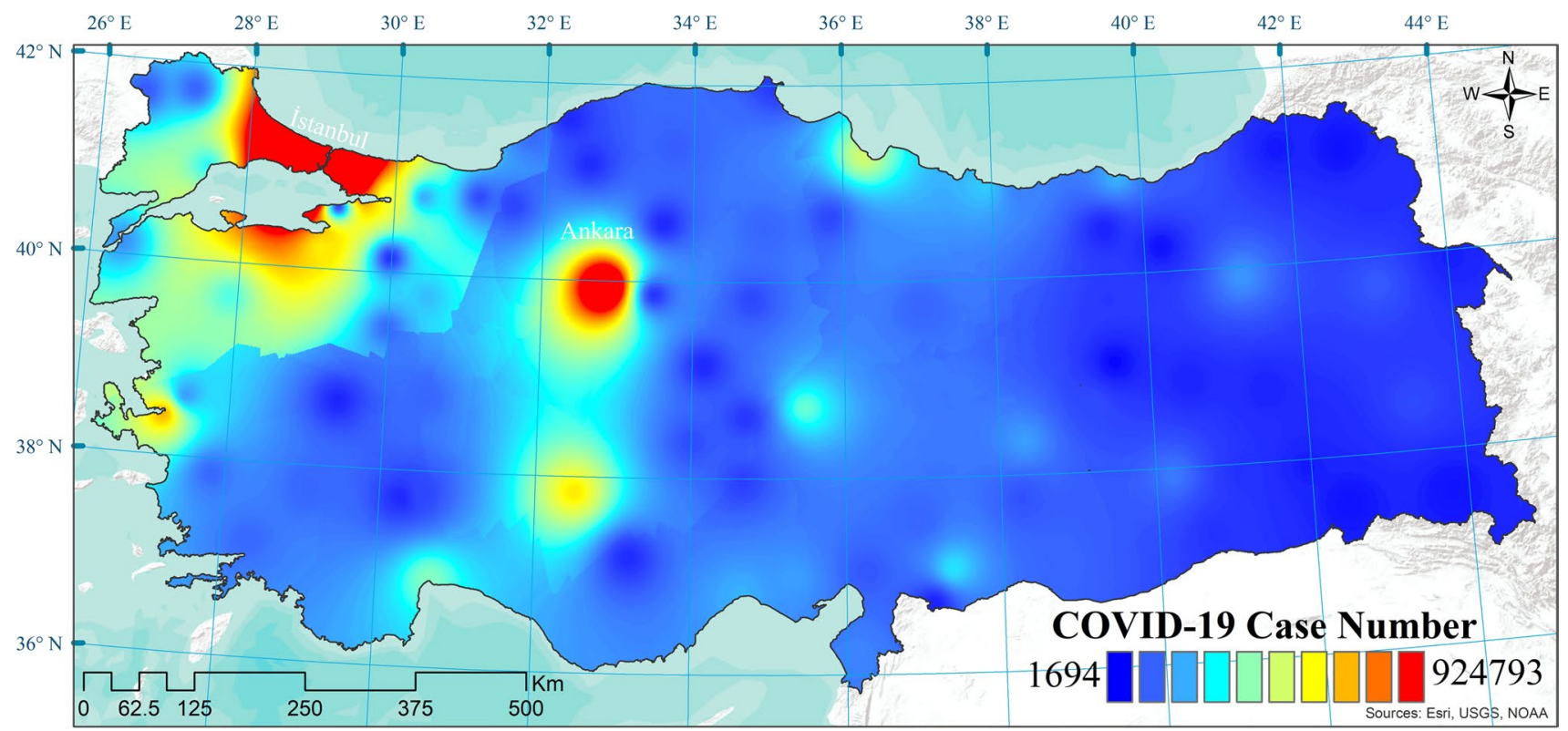

Fig. 2 Distribution of confirmed COVID-19 case numbers in Turkey

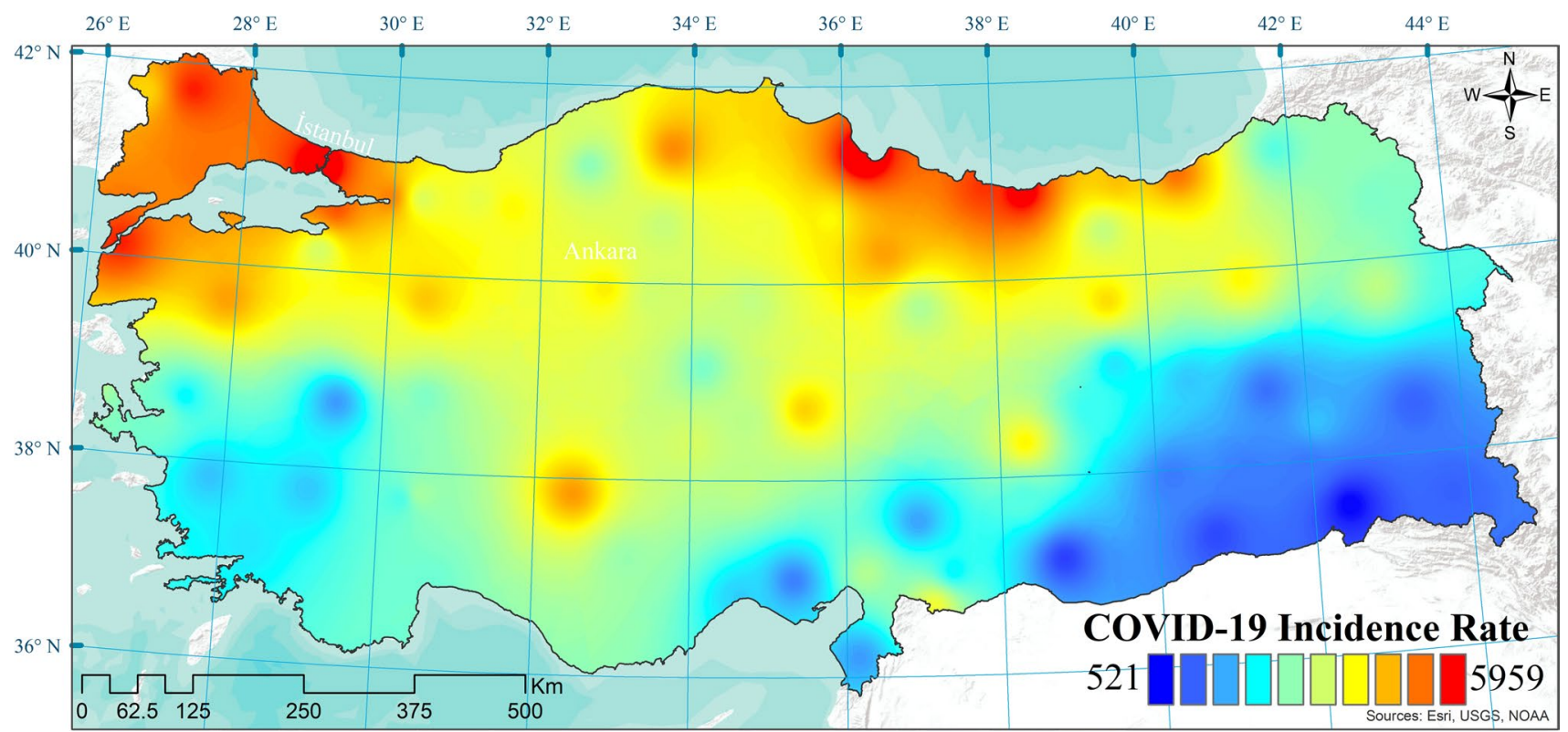

Fig. 3 Distribution of COVID-19 incidence rates in Turkey

Population density shows the population size in the areas where people live. It can be calculated by proportioning the population size with the province's total surface area. Population numbers and case counts have an obvious positive relationship, but the relationship of incidence and population density differs. Figure 4 portrays the population density distribution in different regions of Turkey.

The population density of Turkey is 107.45 people per $\mathrm{km}^{2}$ all over the country. Marmara region is the most densely populated region, including İstanbul $\left(2842 \mathrm{p} / \mathrm{km}^{2}\right)$ and Kocaeli ( $\left.575 \mathrm{p} / \mathrm{km}^{2}\right)$ cities. On the other hand, Erzincan $\left(20 \mathrm{p} / \mathrm{km}^{2}\right)$, Ardahan $\left(19.7 \mathrm{p} / \mathrm{km}^{2}\right)$, and Tunceli $\left(11 \mathrm{p} / \mathrm{km}^{2}\right)$ have the lowest population density in the country. In Turkey, while people living in urban areas are $93 \%$ of the citizens, $7 \%$ of residents live in rural areas (MoH 2018). The median age is 32.4 (Turkstat 2020), the average household size is 3.35 (Turkstat 2019), and according to Turkstat (2018b), the average GDP per capita is 9693 USD. Figure 5 illustrates the 
Table 2 Dependent and independent variables of the study

\begin{tabular}{ll}
\hline Dependent variable & Independent variables \\
\hline COVID-19 incidence rate (case number per 100,000 people) & Population density $\left(\mathrm{p} / \mathrm{km}^{2}\right)$ \\
Urbanization level $(\%)$ & Median age \\
Average household size \\
Gross domestic product (USD) \\
Annual average temperature $\left({ }^{\circ} \mathrm{C}\right)$ \\
Humidity $(\%)$ \\
Annual sunshine duration (h/year) \\
Annual average wind speed (m/s) \\
Air quality index (AQI) \\
Health index \\
Income and wealth index \\
Education index \\
Environment index \\
Social life index \\
Life satisfaction ratio $(\%)$ \\
Number of hospital beds \\
Physician no. (per 1000 people)
\end{tabular}

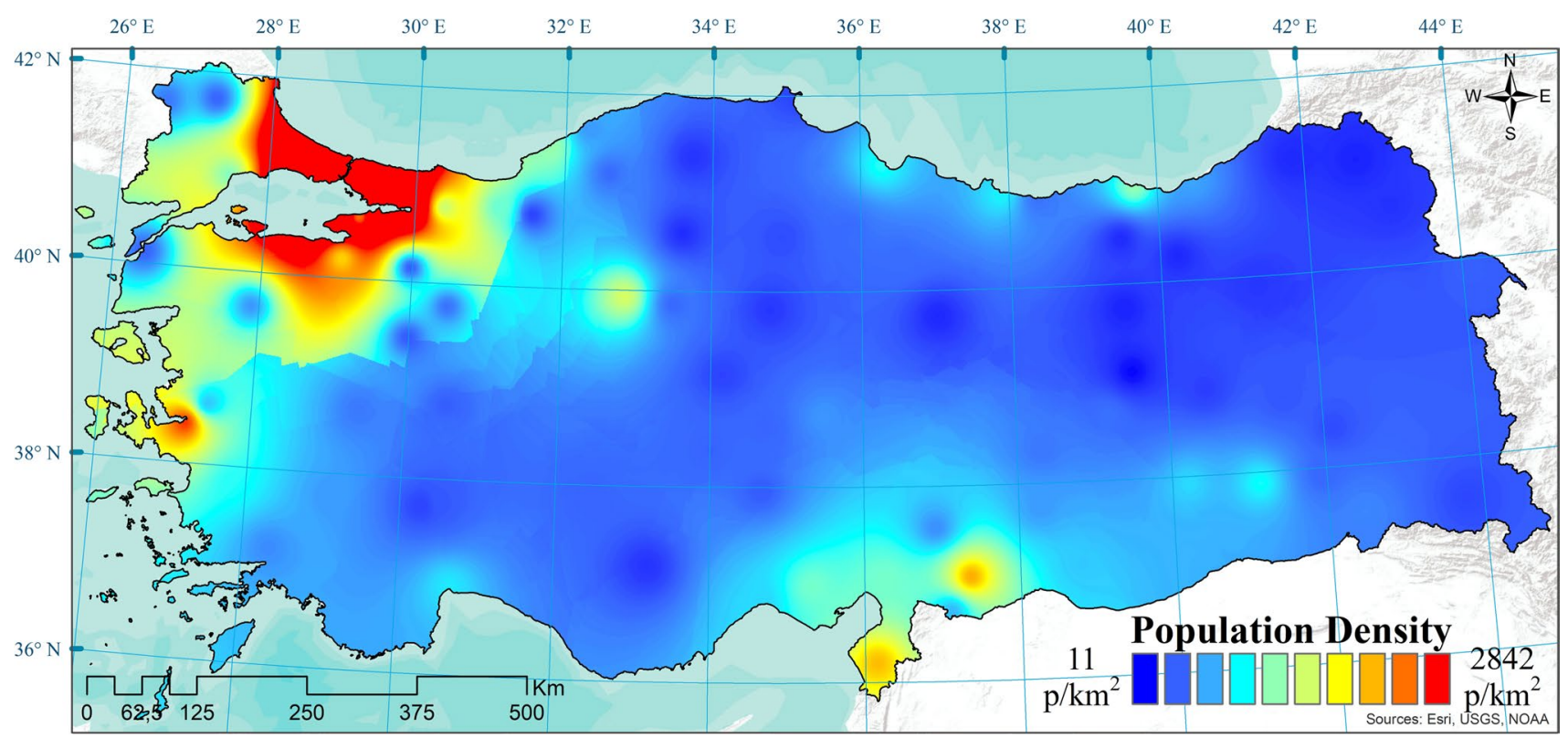

Fig. 4 Population density distribution in Turkey

distribution maps of urban population ratio, household size, median age, and GDP per capita values.

The spatial distribution maps of the meteorological factors in Turkey based on official annual data are given in Fig. 6. While heat is a sum of the kinetic energy of particles that make up a substance, temperature refers to the reflection of this energy to the outside. Temperature is measured by a thermometer and expressed in ${ }^{\circ} \mathrm{C}$ (Doğrusöz 2018). The annual average temperature of Turkey is $13.2{ }^{\circ} \mathrm{C}$. Air quality index (AQI) classifies air pollution to characterize the air quality in particular regions, and it is based on five basic contaminative which are particulate matters (PM10), sulfur dioxide $\left(\mathrm{SO}_{2}\right)$, nitrogen dioxide $\left(\mathrm{NO}_{2}\right)$, ozone $\left(\mathrm{O}_{3}\right)$, and carbon monoxide (CO) emissions (WAQI 2020). AQI data for Turkey has been gathered from IQAir (2020) and MoEU (2021). The average AQI for Turkey is 45.60, which means air pollution poses a minor threat except for some regions with polluted and unhealthy air conditions. The amount of 

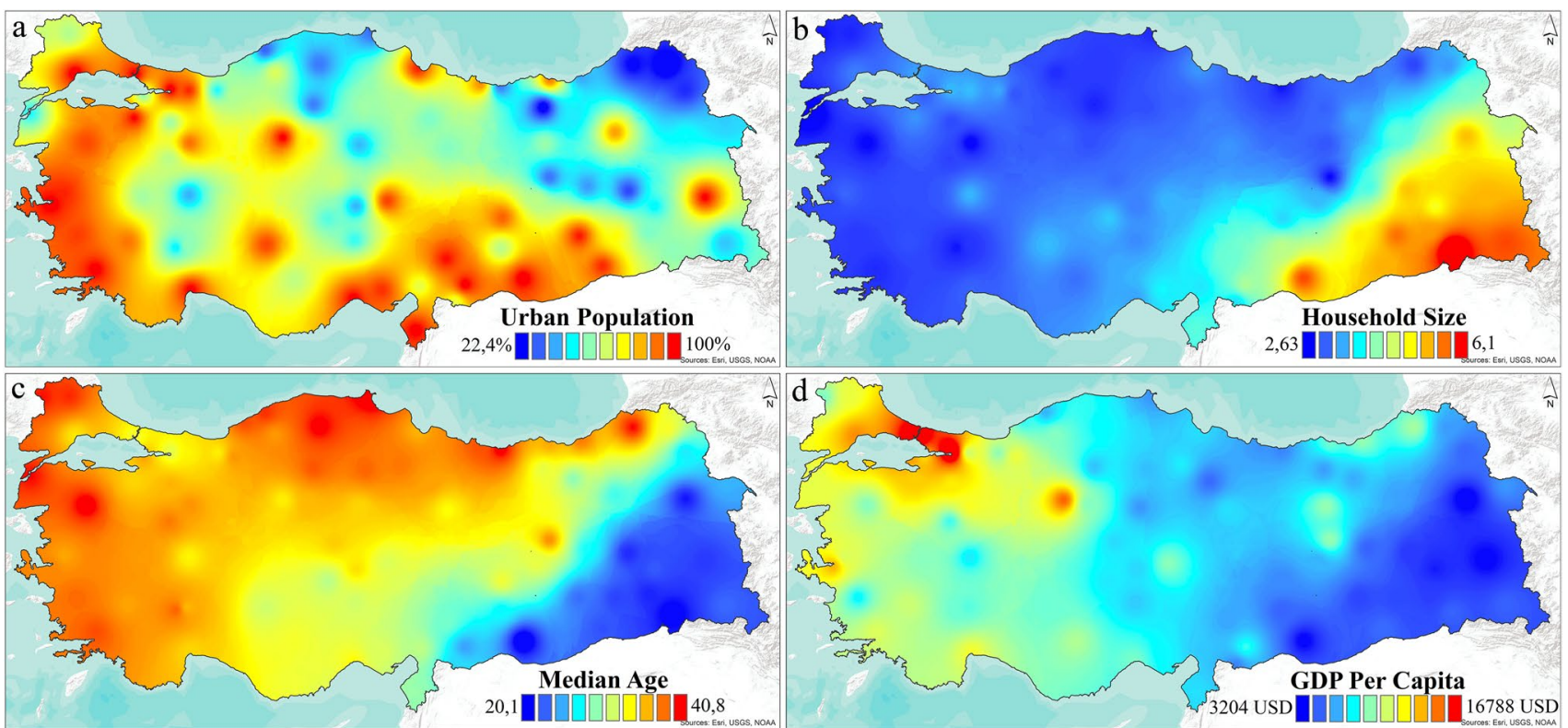

Fig. 5 Spatial distribution maps. a Urban population ratio. b Household size. c Median age. d GDP per capita
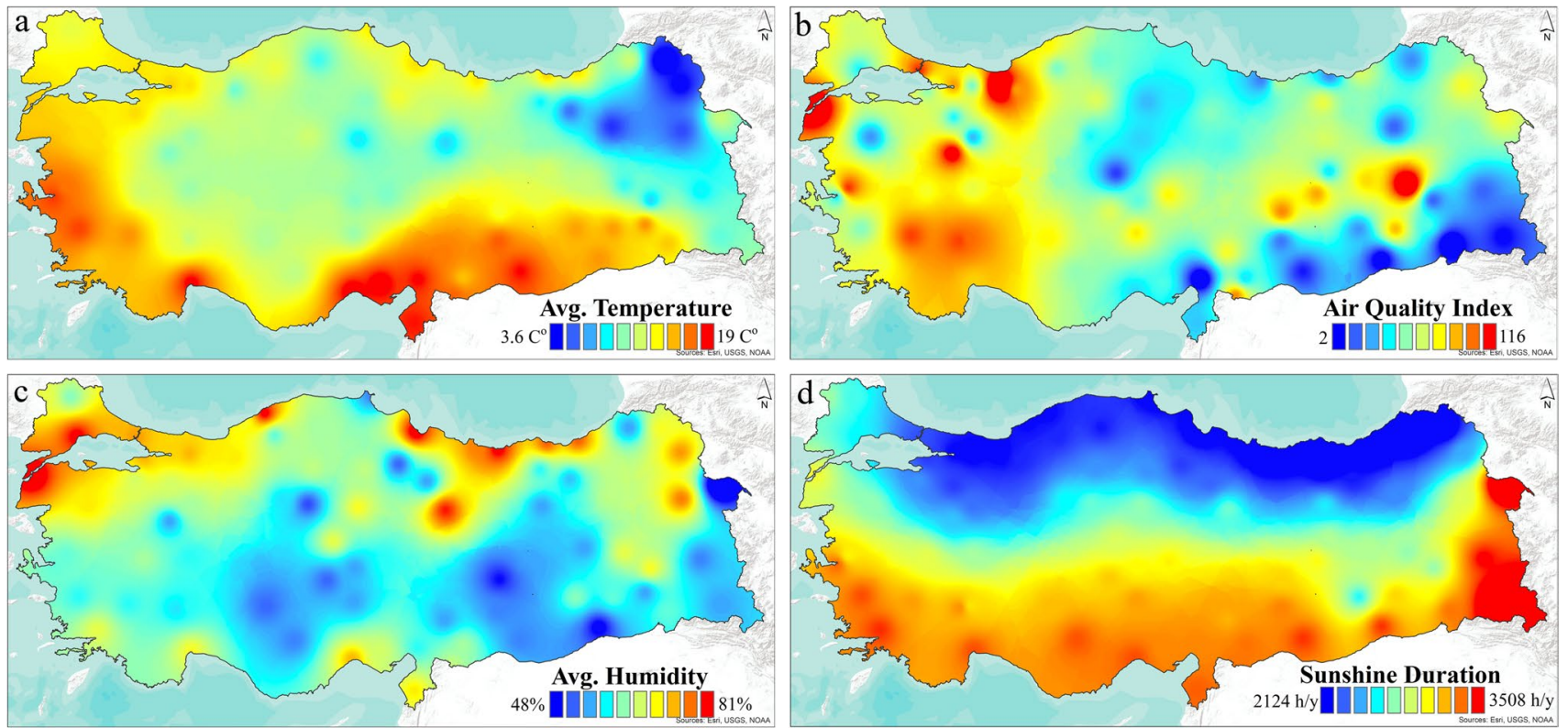

Fig. 6 Annual distribution maps of meteorological conditions in Turkey. a Average temperature. b Air quality index. c Average humidity. d Total sunshine duration in a year

water vapor in the atmosphere is called humidity. A hygrometer is used to measure the humidity of the air. Turkish State Meteorological Service (TSMS 2020a) reported the average relative humidity in Turkey as $63.7 \%$. The length of time that shows how much of the day is sunny is called daily sunshine duration, and it is measured by heliograph. In Turkey, the average daily sunshine duration is $6.6 \mathrm{~h}$ by the measurements between 2011 and 2018 (TSMS 2020b).
The wind is another meteorological factor that may allow the virus to spread in the air and travel longer distances. The average wind speed of Turkey is $2 \mathrm{~m} / \mathrm{s}$ at $10 \mathrm{~m}$ above ground (TSMS 2020b). Figure 7 shows the spatial distribution of wind speed in different regions of Turkey. Çanakkale has the highest wind speed, which is $6.6 \mathrm{~m} / \mathrm{s}$, followed by İzmir $(5 \mathrm{~m} / \mathrm{s})$, Mardin $(4.9 \mathrm{~m} / \mathrm{s})$, and İstanbul $(4.5 \mathrm{~m} / \mathrm{s})$. Provinces with the lowest wind speed 


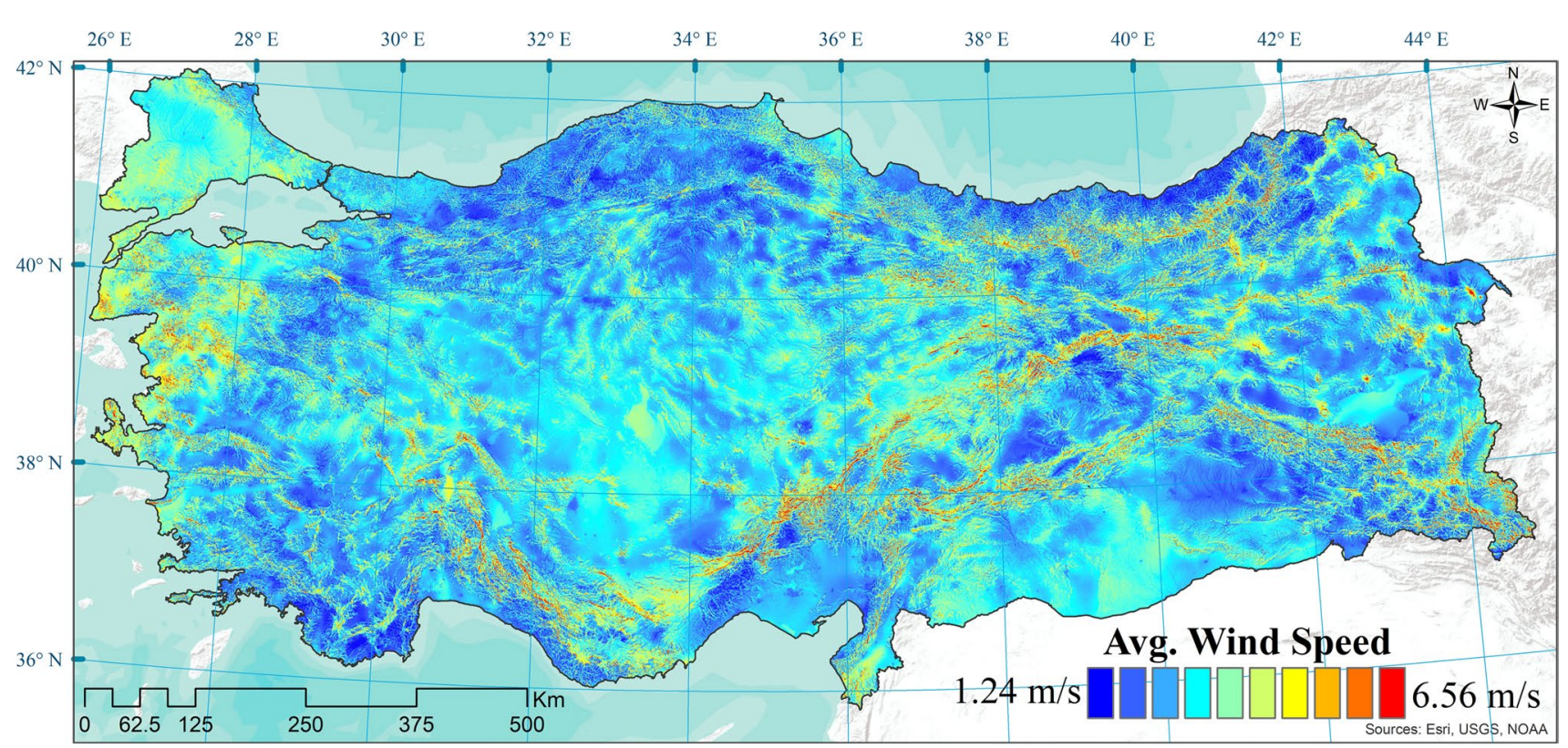

Fig. 7 Annual average wind speed distribution map of Turkey (Süzek 2007; World Bank Group, 2021)

are Gaziantep $(1.4 \mathrm{~m} / \mathrm{s})$, Çankırı $(1.3 \mathrm{~m} / \mathrm{s})$, and Düzce $(1.24 \mathrm{~m} / \mathrm{s})$.

Hospital beds are placed in patient rooms or units where patients are provided with a minimum of $24 \mathrm{~h}$ of medical care (MoH 2018). According to reports of Turkstat (2018a), the average hospital bed number is 2.76 , and the average physician number is 1.5 per 1000 residents in Turkey (Fig. 8).

Life index, produced by the Turkish Statistical Institute based on the OECD Better Life Index, is a study for monitoring and comparing people's living conditions under objective and subjective criteria at a local level. This composite index includes 11 leading indicators and 41 sub-indicators at province-based statistics (Turkstat 2015). However, the primary indicators are housing, career, income and wealth, education, health, safety, environment, civil engagement, social life, access to infrastructure services, and life satisfaction; just five of these indicators have been used in this study to investigate their relationship with COVID-19 patient density. Health index is calculated by some fundamental factors such as satisfaction rate about health infrastructure and public health services available in the cities. The average health index is 0.59 for Turkey. Income and wealth index is calculated by average daily earnings, savings deposit per capita, job satisfaction rate, and percentage of households in the lower-, middle-, and higher-income levels. The average income and wealth index is 0.40 for Turkey. Education index includes the percentage of higher education graduates, schooling ratio of kindergartens, and average points of necessary examinations like the transition to secondary and higher education. The average education index is 0.53 for Turkey. Environment index includes active green area per $\mathrm{km}^{2}$, percentage of the population receiving waste services, satisfaction rate with municipal cleaning services, and infrastructure. The average environment index is 0.59 for Turkey. Social life index is another leading indicator,
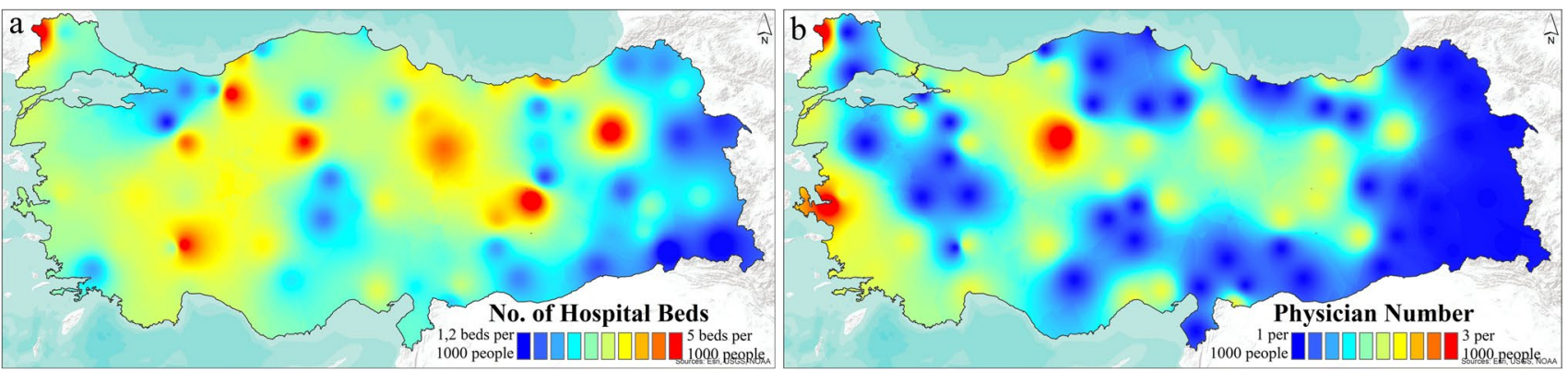

Fig. 8 Spatial distribution of health infrastructure. a Number of hospital beds. b Physician number per 1000 people in Turkey 
including cinema and theater audience ratio, satisfaction rate with social life and social relations, and shopping mall area per thousand people. The average social life index is 0.42 for Turkey. Life satisfaction ratio shows residents' happiness level about their living standards in the provinces where they live. The average life satisfaction ratio is $61.2 \%$ for Turkey (Turkstat 2016). Figure 9 depicts the spatial distribution maps of these indexes in Turkey.

After defining, visualizing, and understanding all the variables, a multiple linear regression analysis will be performed to explore relationships between dependent and independent variables to understand the factors behind observed spatial patterns of COVID-19. However, firstly, it is required to understand the characteristics of the data for further steps. For this purpose, descriptive statistics of all the variables have been prepared in SPSS software and are given in Table 3.

Descriptive statistics are essential to understand that the data is normally distributed or not. For a normal distribution, the central tendency measures like mean and median values must be close to each other as much as possible. Also, smaller standard deviation values mean less spread out of the observations. In addition, if kurtosis and skewness values are between -1 and +1 , that means distribution is inside the range of normality. The degree and direction of asymmetry in the dataset are measured by skewness. If the skewness value is zero, that means a perfectly normal distribution. If the skewness value is positive, the mean value is more than the median in the dataset, and vice versa. By kurtosis value, which is a measure of tail extremity, it is possible to see there are outliers in a distribution or not. Positive and negative kurtosis values show the occurrence of outliers in the dataset (UCLA 2021). Table 3 presents that, although the datasets of the dependent variable and most of the other variables are trustworthy, some independent variables such as household size, population density, and GDP are not entirely reliable due to lack of data. Some scatterplot diagrams have been prepared to understand the relationship between dependent and independent variables; to detect the outliers, if any; and to determine whether a relationship is linear or not (Fig. 10).

The scatterplots in Fig. 10 reveal that there may be a positive association between the incidence rate and population density, median age, GDP, humidity, different types
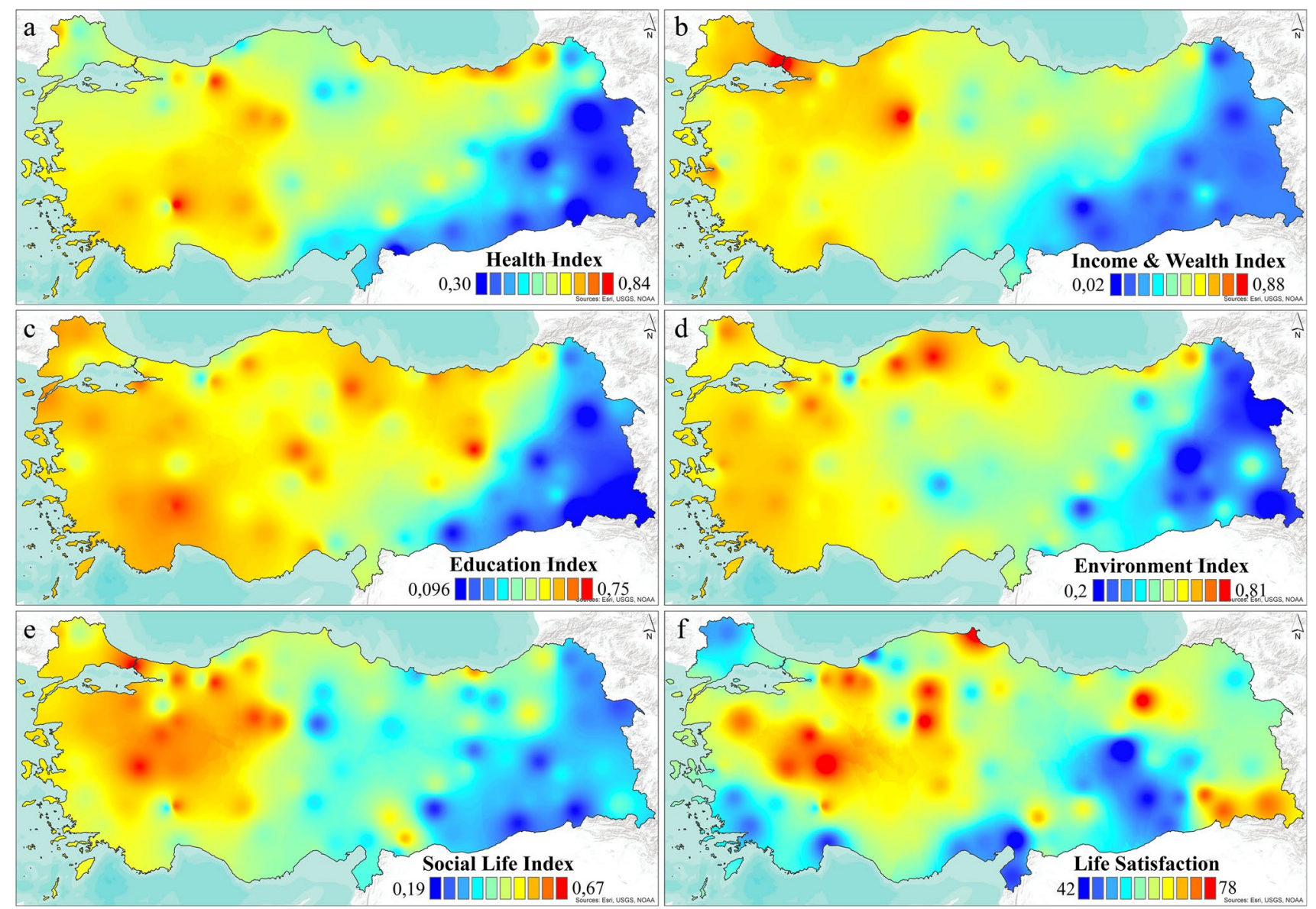

Fig. 9 Life index distribution in Turkey. a Health. b Income and wealth. c Education. d Environment. e Social life. f Life satisfaction ratio 
Table 3 Descriptive statistics of variables

\begin{tabular}{lllllllr}
\hline Variables & Mean & SD & Median & Min & Max & Kurtosis & Skewness \\
\hline COVID-19 incidence rate & 3037 & 1268 & 3003 & 521 & 5959 & -0.55 & 0.22 \\
Population density & 130.2 & 318.7 & 63 & 11.2 & 2842 & 67.5 & 7.93 \\
Urbanization level & 68.4 & 23.75 & 63.40 & 22.40 & 100 & -1.30 & -0.01 \\
Median age & 10.16 & 3.46 & 10.90 & 3.20 & 18.3 & -0.57 & -0.18 \\
Household size & 3.45 & 0.75 & 3.18 & 2.63 & 6.11 & 1.99 & 1.60 \\
GDP & 7250 & 2571 & 6745 & 3204 & 16,791 & 2.79 & 1.32 \\
Avg. temperature & 13.03 & 3.25 & 13.10 & 3.60 & 19.1 & 0.43 & -0.41 \\
Humidity & 66 & 6.75 & 65 & 48 & 81 & -0.28 & 0.24 \\
Annual sunshine duration & 2688 & 283.6 & 2690 & 2124 & 3508 & -0.31 & 0.12 \\
Avg. wind speed (m/s) & 2.70 & 0.93 & 2.56 & 1.24 & 6.56 & 2.76 & 1.23 \\
Air quality index & 45.6 & 21.4 & 41 & 2 & 116 & 1.07 & 0.63 \\
Health index & 0.59 & 0.11 & 0.62 & 0.30 & 0.84 & 0.24 & -0.61 \\
Income and wealth index & 0.40 & 0.17 & 0.44 & 0.02 & 0.88 & -0.03 & -0.22 \\
Education index & 0.53 & 0.14 & 0.57 & 0.10 & 0.75 & 0.89 & -1.12 \\
Environment index & 0.59 & 0.12 & 0.61 & 0.20 & 0.81 & 1.17 & -1.03 \\
Social life index & 0.42 & 0.12 & 0.41 & 0.19 & 0.67 & -0.72 & 0.15 \\
Life satisfaction ratio & 61 & 7.53 & 60.4 & 42 & 77.7 & -0.27 & 0.15 \\
No. of hospital beds & 2.76 & 0.82 & 2.60 & 1.20 & 5.02 & 0.39 & 0.76 \\
Physician no & 1.5 & 0.57 & 1 & 1 & 3 & -0.63 & 0.59 \\
\hline
\end{tabular}

of well-being indexes, and number of hospital beds. There may be moderate or almost no relationship between the dependent variable and urbanization level, wind speed, air quality index, life satisfaction ratio, and physician number. On the other hand, sunshine duration, average temperature, and household size show a negative linear relationship with the incidence rates. For a better understanding, the Pearson correlation coefficient of each independent variable has been calculated to measure the statistical relationship, summarized in Table 4.

The Pearson correlation coefficient changes between -1 and +1 , where -1 indicates a perfect negative correlation while +1 means a perfect positive correlation, and 0 indicates no relationship between the variables. A coefficient value between \pm 0.5 and \pm 1 states a strong correlation, a value between \pm 0.3 and \pm 0.49 means moderate correlation, and a value under \pm 0.29 indicates small correlation (Statistics Solutions 2021). Table 4 presents that sunshine duration and household size have the strongest correlation with the incidence rates. Income level, education index, and median age variables seem like the other strongly correlated factors. Moreover, correlation is significant for all these variables at the 0.01 level. GDP, humidity, health index, environment, social life, and number of hospital beds show a moderate correlation while the other variables have small or no correlation with COVID-19 incidence rates. Descriptive statistics, scatterplot diagrams, and correlation coefficients suggest that model estimates are not biased and have been conducive to understand the data's characteristics and associations between dependent and independent variables. In addition, the data seems well founded for the robustness and accuracy of the regression model. This study has only one dependent variable and eighteen predictors, so a multiple linear regression analysis has been conducted in SPSS software. Table 5 summarizes the model.

In Table 5, $R$ is the multiple correlation coefficient, and its value (0.827) indicates a good level of prediction for the dependent variable. $R^{2}$ value $(0.685)$ means that our exploratory variables explain $68.5 \%$ of the variability of COVID19 incidence rates, while $31.5 \%$ of the variation occurs due to other factors not included in this model. Nevertheless, the model is effective enough to determine the relationship. The adjusted $R^{2}$ value $(0.593)$ means the predictors explain true $59.3 \%$ of the variation in the outcome variable in the model. The standard error of the estimate value $(808,666)$, also called the root mean square error, seems higher than average, but it is acceptable due to the lack of data and sample size used in the study.

To sum up, the model summary table is satisfactory, and the database used in the study is plausible. Therefore, as the next step, the analysis of variance (ANOVA) tool has been used to test whether there is a statistically significant difference between the means of independent groups or not. Table 6 lists the ANOVA results.

In Table 6, the Sig. value ( $p$ value) is less than 0.05 . That means the results are significant and trustworthy. The $F$ ratio is important to see if the overall regression model is a good fit for the data or not. Here, the $F$ ratio value (7.48) is greater than 1 and shows that the exploratory variables statistically 

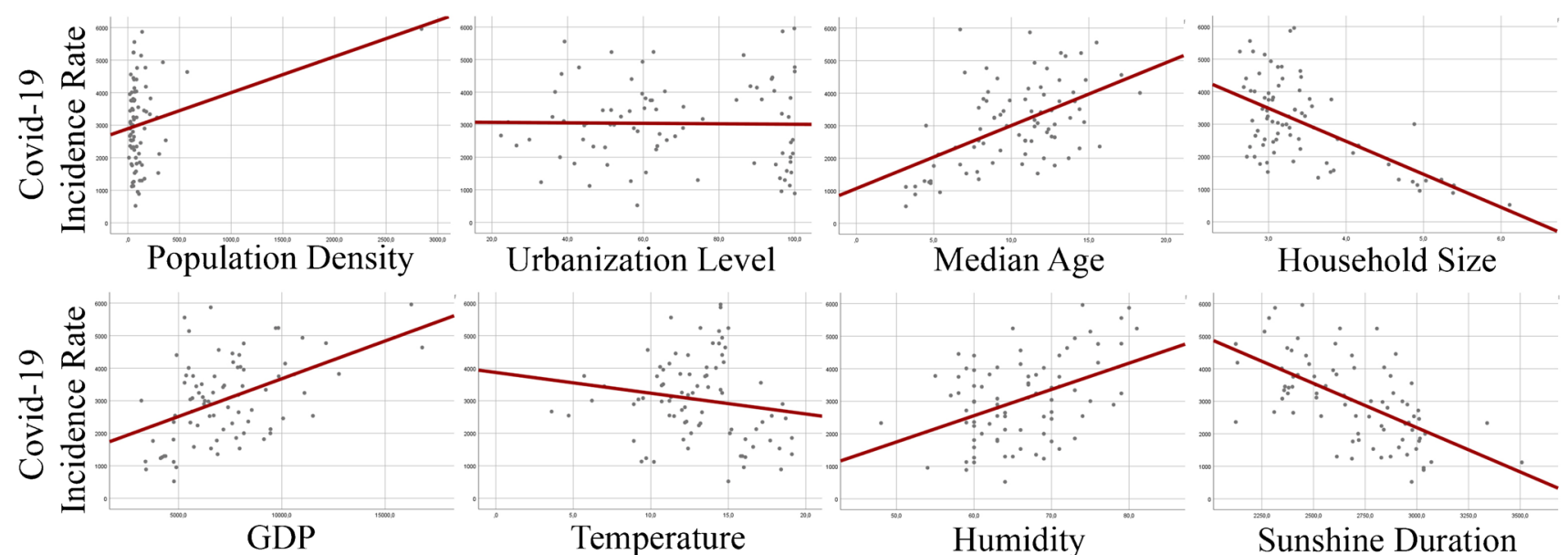

Humidity
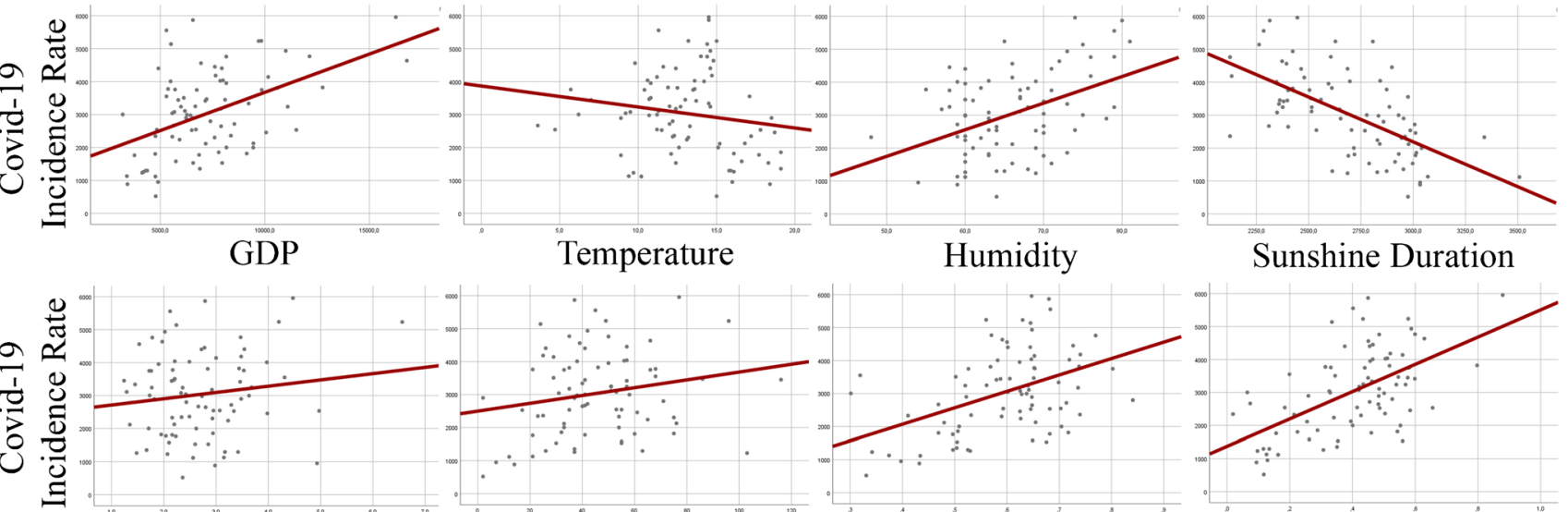

Wind Speed

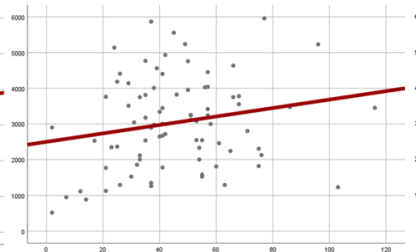

Äir Quality

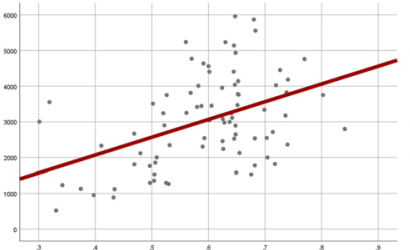

Health Index

Sunshine Duration

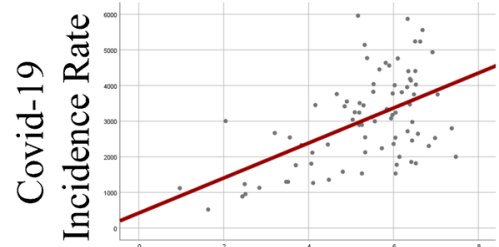

Education Index

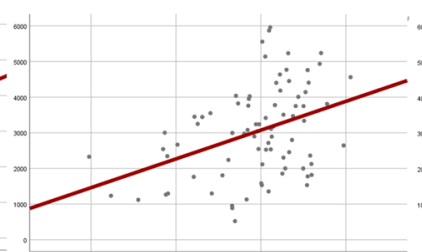

Énvironment Index

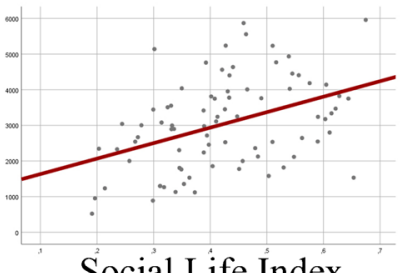

Social Life Índex

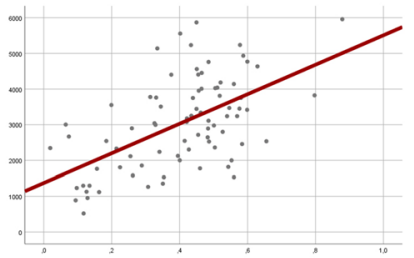

Income \& Wealth
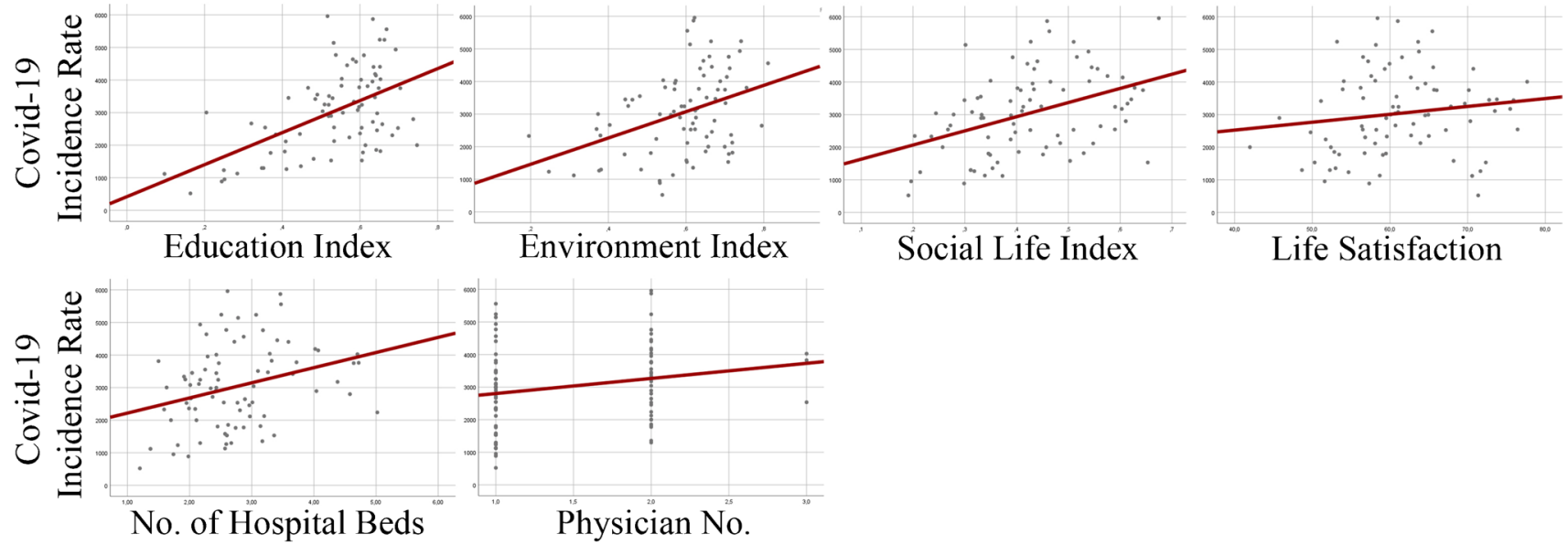

Life Satisfaction

Fig. 10 Scatterplots showing the association between dependent and independent variables

significantly predict the COVID-19 incidence rates. Table 7 summarizes the analysis results for coefficients.

The constant value (732.25) is the predicted value for the dependent variable. That means we can expect the COVID19 incidence rate to be 732.25 anywhere in Turkey. The $B$ column includes the values for predicting the dependent variable from the exploratory variables in the regression equation. In the $B$ column, a 1-unit increase in any positive variable causes an increase in the COVID-19 incidence rate, but each negative value in the column causes a reduction in the dependent variable. The beta weight (beta column) values are the standardized coefficients, and they measure how much the outcome variable changes in standard deviations when the exploratory variable is changed by 1 standard deviation
(Dhakal 2018). Hence, the education index (0.39), median age (0.39), and urbanization level (0.38) seem like the highest contributing predictors to explain COVID-19 incident rates. Zero-order correlation values show the bivariate correlation between the dependent and independent variables. The highest values in this column, sunshine duration value $(-0.61)$ and household size value $(-0.60)$, are the direct effect of these variables on COVID-19 incidence rates. Multicollinearity check is also substantial for a well-specified regression model. Dhakal (2018) says that if the VIF value is higher than 10 or the tolerance value is lower than 0.1 , there is a multicollinearity problem. That means just median age and household size seem as the problematical predictors in the model in terms of multicollinearity, which means 
Table 4 Correlation between dependent and independent variables

Independent variables COVID 19 incidence rate (dependent variable)

\begin{tabular}{lcl}
\cline { 2 - 3 } & Pearson correlation & Sig. (2-tailed) \\
\hline Population density & $0.279^{*}$ & 0.012 \\
Urbanization level & -0.014 & 0.903 \\
Median age & $0.529 * *$ & 0.000 \\
Household size & $-0.602 * *$ & 0.000 \\
GDP & $0.471^{* *}$ & 0.000 \\
Average temperature & -0.16 & 0.144 \\
Humidity & $0.430^{* *}$ & 0.000 \\
Sunshine duration & $-0.609 * *$ & 0.000 \\
Average wind speed & 0.14 & 0.211 \\
Air quality index & 0.2 & 0.074 \\
Health index & $0.442 * *$ & 0.000 \\
Income and wealth index & $0.564 * *$ & 0.000 \\
Education index & $0.534 * *$ & 0.000 \\
Environment index & $0.383^{* *}$ & 0.000 \\
Social life index & $0.413 * *$ & 0.000 \\
Life satisfaction ratio & 0.144 & 0.200 \\
No. of hospital beds & $0.302 * *$ & 0.006 \\
Physician no & 0.21 & 0.061 \\
\hline
\end{tabular}

*Correlation is significant at the 0.05 level (2-tailed).

**Correlation is significant at the 0.01 level (2-tailed).

Table 5 Multiple regression analysis model summary

\begin{tabular}{lllll}
\hline Model & $R$ & $R^{2}$ & Adjusted $R^{2}$ & Std. error of the estimate \\
\hline 1 & 0.827 & 0.685 & 0.593 & 808,666 \\
\hline
\end{tabular}

Table 6 ANOVA results

\begin{tabular}{lcrrrr}
\hline Model & \multicolumn{1}{l}{ ANOVA } & & & & \\
\cline { 2 - 6 } & Sum of squares & $d f$ & Mean square & $F$ & Sig \\
\hline 1 & & & & & \\
Regression & $88,045,400.1$ & 18 & $4,891,411.117$ & 7.480 & 0.000 \\
Residual & $40,544,315.45$ & 62 & $653,940.572$ & & \\
Total & $128,589,715.6$ & 80 & & & \\
\hline
\end{tabular}

there is a very high relationship between these two variables. Therefore, the median age has been excluded from the final regression model. In the most important column, significance values show that urbanization level $(p(0.006)<0.05)$, average temperature $(p(0.01)<0.05)$, sunshine duration $(p(0.029)<0.05)$, wind speed $(p(0.038)<0.05)$, and education index $(p(0.036)<0.05)$ are statistically significant to be used in the model while the others are not more useful in the model. The analyses show that the regression model is not specified well enough, and there is multicollinearity among some of the variables. Thus, a final regression model has been tested by using only the statistically significant exploratory predictors. Table 8 gives the model summary of the final regression analysis.

$R$ value (0.755) indicates a good level of prediction for the dependent variable. $R^{2}$ value $(0.570)$ indicates that these five variables explain 57\% of the variability of COVID-19 incidence rates, while $43 \%$ of the variation is because of other factors not included in this study. Adjusted $R^{2}$ value (0.542) means true $54.2 \%$ of the variation in the COVID19 incidence rate is explained by the predictors in the final model. As an additional and final analysis, spatial dependency among the COVID-19 incidence rate observations was tested using the ArcGIS Spatial Autocorrelation (Global Moran's I) tool, and a statistically significant spatial cluster pattern was found (Fig. 11).

In Fig. 11, the $z$-score is +7.20 , which means the analyzed attributes are not randomly distributed among the features in the area, and COVID-19 incident rates are clustered in some regions in Turkey. Also, the $p$ value (significance level) in the analysis is less than 0.01 and seems statistically significant, and the regression model used in this study has a confidence level of $99 \%$. That means the model is genuinely specified, and results can be trusted.

\section{Discussion}

The distribution of COVID-19 incidence rates was examined for Turkey to understand how a province's spatial and nonspatial structure can regulate the overall pattern, and the results were found to be heterogeneous across Turkey. While some regions have higher incidence rates than usual, some regions have lower rates than expected. This clustered distribution could be attributed to many corresponding factors such as geographical, physical, environmental, sociocultural, socioeconomical, demographic, and meteorological differences among the provinces. A multiple linear regression analysis has been conducted to determine the relationship between COVID-19 incidence rates and the chosen explanatory variables. Based on the COVID-19 incidence rate distribution map and spatial autocorrelation results, it seems that Marmara, Mid-Black Sea, and Eastern Black Sea regions have the highest incidence rates while Southeast Anatolia and south part of Eastern Anatolia regions have the lowest rates as clustered. For instance, the incidence rate (cases per 100,000 people) was found maximum in İstanbul, Kırklareli, Çanakkale, Yalova, Tekirda ̌̆, Kocaeli (Marmara Region), and Samsun, Giresun, Ordu, and Rize (Middle and Eastern Black Sea), while the incidence rate was found minimum in Mardin, Sanliurfa, Siirt (Southeast Anatolia Region), and Şırnak, Hakkâri, and Van (south part of Eastern Anatolia Region) provinces. Sunshine duration, urbanization ratio, 
Table 7 Coefficients

\begin{tabular}{|c|c|c|c|c|c|c|c|c|}
\hline & \multicolumn{8}{|l|}{ Coefficients } \\
\hline & \multicolumn{2}{|c|}{ Unstandardized coefficients } & \multirow{2}{*}{$\begin{array}{l}\text { Std. coefficients } \\
\text { Beta }\end{array}$} & \multirow[t]{2}{*}{$t$} & \multirow[t]{2}{*}{ Sig } & \multirow{2}{*}{$\begin{array}{l}\text { Correlation } \\
\text { Zero-order }\end{array}$} & \multicolumn{2}{|c|}{ Collinearity statistics } \\
\hline & $B$ & Std. error & & & & & Tolerance & VIF \\
\hline Constant & 732.25 & 3590.74 & & 0.20 & 0.839 & & & \\
\hline Population density & 0.63 & 0.39 & 0.16 & 1.62 & 0.110 & 0.28 & 0.53 & 1.90 \\
\hline Urbanization level & 20.38 & 7.23 & 0.38 & 2.82 & 0.006 & -0.01 & 0.27 & 3.76 \\
\hline Median age & 142.36 & 85.59 & 0.39 & 1.66 & 0.101 & 0.53 & 0.09 & 11.20 \\
\hline Household size & -61.94 & 447.35 & -0.04 & -0.14 & 0.890 & -0.60 & 0.07 & 14.46 \\
\hline GDP & 0.14 & 0.08 & 0.29 & 1.85 & 0.069 & 0.47 & 0.20 & 5.06 \\
\hline Average temperature & -124.32 & 46.98 & -0.32 & -2.65 & 0.010 & -0.16 & 0.34 & 2.98 \\
\hline Humidity & 28.01 & 15.93 & 0.15 & 1.76 & 0.084 & 0.43 & 0.68 & 1.48 \\
\hline Sunshine duration & -1.16 & 0.52 & -0.26 & -2.24 & 0.029 & -0.61 & 0.36 & 2.75 \\
\hline Wind speed & 218.83 & 103.26 & 0.16 & 2.12 & 0.038 & 0.14 & 0.84 & 1.18 \\
\hline Air quality index & 3.42 & 5.23 & 0.06 & 0.65 & 0.515 & 0.20 & 0.63 & 1.59 \\
\hline Health index & -2808.09 & 1571.06 & -0.25 & -1.79 & 0.079 & 0.44 & 0.25 & 3.97 \\
\hline Income and wealth index & 339.54 & 1234.84 & 0.05 & 0.27 & 0.784 & 0.56 & 0.17 & 5.81 \\
\hline Education index & 3631.78 & 1693.58 & 0.39 & 2.14 & 0.036 & 0.53 & 0.14 & 6.94 \\
\hline Environment index & -3004.62 & 1533.00 & -0.29 & -1.96 & 0.0545 & 0.38 & 0.23 & 4.34 \\
\hline Social life index & -1089.11 & 1495.66 & -0.10 & -0.73 & 0.470 & 0.41 & 0.24 & 4.14 \\
\hline Life satisfaction ratio & 30.58 & 17.13 & 0.18 & 1.79 & 0.079 & 0.14 & 0.47 & 2.12 \\
\hline No. of hospital beds & 207.48 & 174.55 & 0.13 & 1.19 & 0.239 & 0.30 & 0.38 & 2.63 \\
\hline Physician no & -280.18 & 226.30 & -0.13 & -1.24 & 0.220 & 0.21 & 0.47 & 2.14 \\
\hline
\end{tabular}

Table 8 Final regression analysis model summary

\begin{tabular}{lllll}
\hline Model & \multicolumn{4}{l}{ Model summary } \\
\cline { 2 - 5 } & $R$ & $R^{2}$ & Adjusted $R^{2}$ & Std. error of the estimate \\
\hline 1 & $0.755^{\mathrm{a}}$ & 0.570 & 0.542 & 858.171 \\
\hline
\end{tabular}

a Predictors: constant, urbanization ratio, sunshine duration, average temperature, wind speed, and education index.

wind speed, education index, and average temperature maps have similar spatial distribution by their correlation values. These statistical results indicate that the rate of COVID-19 incidences must be considered for unbiased estimation and compelling interpretation of the results.

Statistical results of this study show that:

- As the urbanization ratio of cities increases, the COVID19 incidence rate increases.

- As the education index increases, the COVID-19 incidence rate increases, too.

- As the sunshine duration increases, the COVID-19 incidence rate decreases.

- As the average temperature increases, the COVID-19 incidence rate decreases.

- As the wind speed increases, the COVID-19 incidence rate increases.
Transmission of the virus increases with the social and spatial interaction between people, so urbanized areas are favorable environments for the spread of outbreaks because of their higher building and population density. So, the positive association between the urbanization ratio and the incidence rates is reasonable and acceptable. Furthermore, educated people generally live in bigger cities such as İstanbul, İzmir, and Ankara, which are significant attraction points. The percentage of higher education graduates, schooling ratio of kindergartens, university number, and average points of necessary examinations like the transition to secondary and higher education are higher in these cities, too. Thus, the positive correlation between the education index and the incidence rate makes sense since educated people prefer to live in urbanized areas. Many recent studies report that daily sunshine duration and average air temperature negatively correlate with COVID-19 incident rates. In addition, many kinds of research in different parts of the world show that wind increases virus spread directly by increasing air circulation among people, cities, and regions.

\section{Conclusion}

In conclusion, this study has tested eighteen potential factors on the COVID-19 incidence rate. Five of them (urbanization ratio, education index, sunshine duration, 
Fig. 11 Spatial autocorrelation (Moran's I) results for COVID19 incident rates

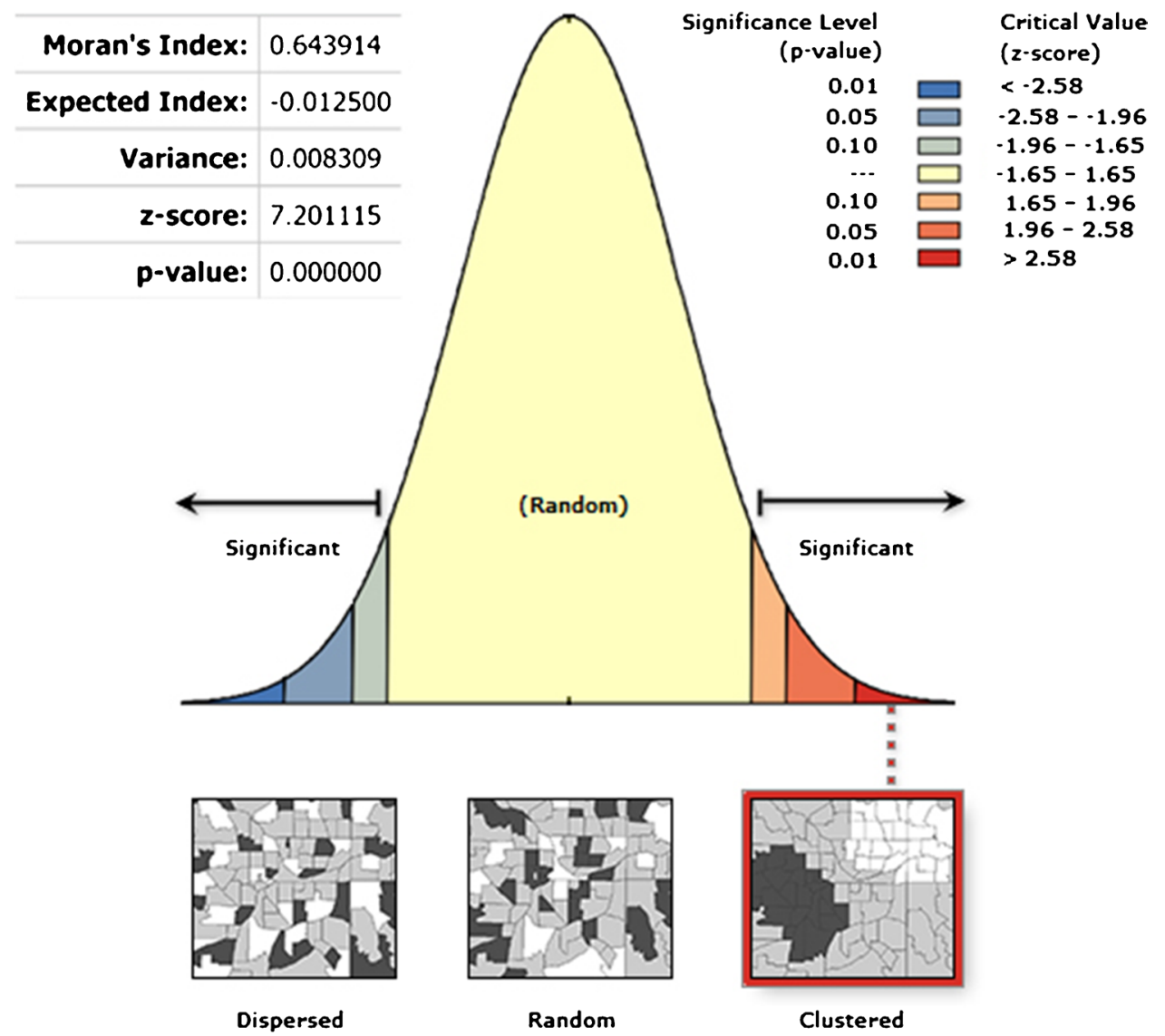

average temperature, and wind speed) have been found statistically significant due to the multiple linear regression analysis processes. As a result, it is recognized that these five factors can explain $57 \%$ of the variability of COVID-19 incidence rates in Turkey, while $43 \%$ of the variation is due to other factors not included in this study. That means after this study and thousands of other related studies, COVID-19 still stands as a complex phenomenon that is not fully understood, and its causes have not been entirely resolved. Today, billions of people continue living together in cities without knowing the fundamental dynamics of this virus, but we have to find out all the reasons and solutions as soon as possible to finish this outbreak. We have to comprehend that an alternative lifestyle emerging toward the COVID-19 pandemic is not a location-independent phenomenon. All human beings and most of their activities are related to space, so all occupational groups dealing with space, especially urban planners, must think about the effects of social and spatial urban life on the disease's spread. However, the study's model and the results are trustworthy; the eighteen factors examined in this study do not explain all reasons for different spread rates of COVID-19 in different regions. This complex phenomenon cannot be explained by a single discipline such as medicine, sociology, urban planning, or psychology. All human-related disciplines must combine their data, experience, and knowledge to identify a collectively exhaustive list of significant factors affecting the spread rates. Governments and non-governmental organizations, public and private sectors, universities, and all kinds of actors must unite their forces against COVID-19 disease to solve the current problems and to design the post-pandemic cities of the near future.

Author contribution I made all the contributions for the conceptual framework of the study and collected, processed, analyzed, and interpreted all the data, maps, and tables. In addition, I approve that the work is ready for publication, and I accept the responsibility for all of the work.

Data availability Materials presented in this manuscript are available upon request from the author.

Code availability Not applicable.

\section{Declarations}

Ethics approval and consent to participate Not applicable.

Consent for publication Not applicable.

Conflict of interest The author declares no competing interests. 


\section{References}

Ahmadi M Sharifi A Dorosti S Ghoushchi SJ Ghanbari N (2020) Investigation of effective climatology parameters on COVID-19 outbreak in Iran. Sci Total Environ. https://doi.org/10.1016/j.scito tenv.2020.138705

Ali I Alharbi OM (2020) COVID-19: disease, management, treatment, and social impact. Sci Total Environ. https://doi.org/10.1016/j. scitotenv.2020.138861

Alirol E, Getaz L, Stoll B, Chappuis F, Loutan L (2011) Urbanisation and infectious diseases in a globalised world. Lancet Infect Dis 11(2):131-141

Almagro M Orane-Hutchinson A (2020) JUE insight: the determinants of the differential exposure to COVID-19 in New York City and their evolution over time. J Urban Econ. https://doi.org/10.1016/j. jue.2020.103293

Andree BP (2020) Incidence of COVID-19 and connections with air pollution exposure: evidence from the Netherlands. SSRN. https:// ssrn.com/abstract $=3584842$. Accessed 10 July 2021

Arif M Sengupta S (2021) Nexus between population density and novel coronavirus (COVID-19) pandemic in the south Indian states: a geo-statistical approach. Environ Dev Sustain. https://doi.org/10. 1007/s10668-020-01055-8

Auler AC Cássaro FAM Silva VO Pires LF (2020) Evidence that high temperatures and intermediate relative humidity might favor the spread of COVID-19 in tropical climate: a case study for the most affected Brazilian cities. Sci Total Environ. https://doi.org/10. 1016/j.scitotenv.2020.139090

Bashir MF, Ma B, Bilal KB, Bashir MA, Tan D, Bashir M (2020) Correlation between climate indicators and COVID-19 pandemic in New York. Sci Total Environ, USA. https://doi.org/10.1016/j.scito tenv.2020.138835

Bhadra A Mukherjee A Sarkar K (2021) Impact of population density on Covid-19 infected and mortality rate in India. Model Earth Syst Environ. https://doi.org/10.1007/s40808-020-00984-7

Carozzi F, Provenzano S, Roth S (2020) Urban density and COVID-19. IZA Institute of Labor Economics. https://papers.ssrn.com/sol3/ papers.cfm?abstract_id=3643204. Accessed 17 July 2021

Chen B, Liang H, Yuan X, Hu Y, Xu M, Zhao Y et al (2020) Roles of meteorological conditions in COVID-19 transmission on a worldwide scale. medRxiv. https://doi.org/10.1101/2020.03.16. 20037168

Coşkun H Yıldırım N Gündüz S (2021) The spread of COVID-19 virus through population density and wind in Turkey cities. Sci Total Environ. https://doi.org/10.1016/j.scitotenv.2020.141663

Demir E (2019) R Diliyle İstatistik Uygulamaları. Pegem Akademi, Ankara

Dhakal C (2018) Interpreting the basic outputs (SPSS) of multiple linear regression. Int J Sci Res. https://www.ijsr.net/archive/v8i6/ 4061901.pdf. Accessed 22 July 2021

Doğanay H, Orhan F (2019) Türkiye Beşeri Coğrafyası. PEGEM Akademi, Ankara

Doğrusöz K (2018) İklim Bilgisi. Palme Yayınevi, Ankara

Doremalen NV Bushmaker T Morris DH Holbrook MG Gamble A et al (2020) Aerosol and surface stability of SARS-CoV-2 as compared with SARS-CoV-1. N Engl J Med. https://doi.org/10.1101/2020. 03.09.20033217

Ersöz F, Ersöz T (2019) İstatistik-I Kavram, Teori, Parametrik Testler. Seçkin Teknik, Ankara

Fattorini D Regoli F (2020) Role of the chronic air pollution levels in the Covid-19 outbreak risk in Italy. Environ Pollut. https:// doi.org/10.1016/j.envpol.2020.114732

Frontera A Claire M Kostantinos V Giovanni S (2020) Regional air pollution persistence links to COVID-19 infection zoning. J Infect. https://doi.org/10.1016/j.jinf.2020.03.045
Gavi (2020) 5 reasons why pandemics like COVID-19 are becoming more likely. Geneva, Switzerland. https://www.gavi.org/vacci neswork/5-reasons-why-pandemics-like-covid-19-are-becom ing-more-likely. Accessed 21 July 2021

Gupta A Banerjee S Das S (2020) Significance of geographical factors to the COVID-19 outbreak in India. Model Earth Syst Environ. https://doi.org/10.1007/s40808-020-00838-2

Hamidi S Sabouri S Ewing R (2020) Does density aggravate the COVID-19 pandemic? J Am Plann Assoc. https://doi.org/10. $1080 / 01944363.2020 .1777891$

Hays JN (2009) The burdens of disease epidemics and human response in Western history. Rutgers University Press.

Helen A (2020) Air pollution impact on COVID-19 mortality shocks scientists. BreezoMeter. https://blog.breezometer.com/air-pollu tion-impact-on-covid-19-mortality-shocks-scientists. Accessed 19 July 2021

IQAir (2020) Air quality in Turkey. Staad, Switzerland. www.iqair. com/turkey Accessed 23 July 2021

Iqbal N Fareed Z Shahzad F He X Shahzad U Lina M (2020) The nexus between COVID-19, temperature and exchange rate in Wuhan City: new findings from partial and multiple wavelet coherence. Sci Total Environ. https://doi.org/10.1016/j.scito tenv. 2020.138916

JHU (2022) COVID-19 dashboard by the Center for Systems Science and Engineering (CSSE) at Johns Hopkins University. JHU: https://coronavirus.jhu.edu/map.html. Accessed 6 February 2022

Jing QL Liu MJ Zhang ZB Fang LQ Yuan J et al (2020) Household secondary attack rate of COVID-19 and associated determinants in Guangzhou, China: a retrospective cohort study. Lancet Infect Dis. https://doi.org/10.1016/S1473-3099(20)30471-0

Karataş Z (2014) Regresyon. Recep Tayyip Erdoğan University, Rize, Korelasyon ve Faktör Analizi

Korber R (2020) Severe coronavirus \& poor air quality could be linked. BreezoMeter. https://blog.breezometer.com/coronavirus-air-quali ty-connection. Accessed 16 July 2021

Mansour S Al Kindi A Al-Said A Al-Said A Atkinson P (2021) Sociodemographic determinants of COVID-19 incidence rates in Oman: geospatial modelling using multiscale geographically weighted regression (MGWR). Sustain Cities Soc. https://doi. org/10.1016/j.scs.2020.102627

Megahed NA Ghoneim EM (2020) Antivirus-built environment: lessons learned from Covid-19 pandemic. Sustain Cities Soc. https:// doi.org/10.1016/j.scs.2020.102350

Mehmood K Bao Y Abrar MM Petropoulos GP et al (2021) Spatiotemporal variability of COVID-19 pandemic in relation to air pollution, climate and socioeconomic factors in Pakistan. Chemosphere. https://doi.org/10.1016/j.chemosphere.2021.129584

Mishra SV Gayen A Haque SM (2020) COVID-19 and urban vulnerability in India. Habitat Int. https://doi.org/10.1016/j.habitatint. 2020.102230

MoAF (2019) Corine map. Republic of Turkey Ministry of Agriculture and Forestry. https://corinecbs.tarimorman.gov.tr/corine. Accessed 15 July 2021

MoEU (2011) Türkiye Çevre Durum Raporu. Republic of Turkey Ministry of Environment and Urbanisation.https://webdosya.csb.gov. tr/db/ced/icerikler/tcdr_2011-20180308151518.pdf. Accessed 16 July 2021

MoEU (2021) Air quality monitoring system. Turkish Republic Ministry of Environment and Urbanisation, Ankara. https://sim.csb. gov.tr/Services/AirQuality. Accessed 16 July 2021

MoH (2018) Turkey health statistics yearbook 2018. General Directorate of Health Information Systems. Republic of Turkey Ministry of Health. https://ohsad.org/wp-content/uploads/2020/01/SB_istat istik-yıllığı-2018_en.pdf. Accessed 8 July 2021 
MoH (2021) Current situation in Turkey. Republic of Turkey Ministry of Health. https://covid19.saglik.gov.tr/TR-66935/genel-koron avirus-tablosu.html. Accessed 17 July 2021

Qi H Xiao S Shi R Ward MP Chen Y Tu W et al (2020) COVID-19 transmission in Mainland China is associated with temperature and humidity: a time-series analysis. Sci Total Environ. https:// doi.org/10.1016/j.scitotenv.2020.138778

Reniers R (2020) Why do young people take more risks against social distancing? University of Birmingham. Birmingham, UK. https:// www.birmingham.ac.uk/research/perspective/young-people-riskssocial-distancing.aspx. Accessed 12 July 2021

Rocklöv J Sjödin H (2020) High population densities catalyse the spread of COVID-19. J Travel Med. https://doi.org/10.1093/jtm/ taaa038

Saadat S Deepak R Hussain CM (2020) Environmental perspective of COVID-19. Sci Total Environ. https://doi.org/10.1016/j.scito tenv.2020.138870

Şahin M (2020) Impact of weather on COVID-19 pandemic in Turkey. Sci Total Environ. https://doi.org/10.1016/j.scitotenv.2020.138810

Sands P, El Turabi A, Saynisch PA, Dzau VJ (2016) Assessment of economic vulnerability to infectious disease crises. Lancet 388(10058):2443-2448. https://doi.org/10.1016/S0140-6736(16) 30594-3

Sarkar S Ekram K Das P (2021) Spatial modeling of COVID-19 transmission in Bangladesh. Spat Inf Res. https://doi.org/10.1007/ s41324-021-00387-5

Statistics Solutions (2021) Pearson's correlation coefficient. https:// www.statisticssolutions.com/free-resources/directory-of-statistical-analyses/pearsons-correlation-coefficient/. Accessed 23 July 2021

Süzek F (2007) Türkiye Rüzgar Enerjisi Potansiyelinin Belirlenmesi. MSc Thesis. İstanbul Technical University.

Thangariyal S, Rastogi A, Tomar A, Bhadoria AS, Baweja S (2020) Impact of temperature and sunshine duration on daily new cases and death due to COVID-19. J Family Med Prim Care. https:// www.jfmpc.com/text.asp?2020/9/12/6091/305561. Accessed 18 July 2021

Tosepu R, Gunawan J, Effendy DS, Ahmad LO et al (2020) Correlation between weather and Covid-19 pandemic in Jakarta, Indonesia. Sci Total Environ. https://doi.org/10.1016/j.scitotenv.2020.138436

TSMS (2020a) Turkey average humidity. Turkish State Meteorological Service. https://www.mgm.gov.tr/iklim/iklim-raporlari.aspx. Accessed 20 July 2021

TSMS (2020b) General meteorological statistics for Turkish provinces. Ankara: Turkish State Meteorological Service. https://www.mgm. gov.tr/eng/forecast-cities.aspx. Accessed 20 July 2021

Turkstat (2015) Rankings and index values of well-being index for provinces. Turkish Statistical Institute. http://www.tuik.gov.tr/ PreTablo.do?alt_id=1106. Accessed 11 July 2021
Turkstat (2016) Life satisfaction survey. Turkish Statistical Institute. http://www.tuik.gov.tr. Accessed 16 July 2021

Turkstat (2018a) Total physician number per 1000 people. Turkish Statistical Institute

Turkstat (2018b) Gross domestic product per capita. Turkish Statistical Institute

Turkstat (2019) Average household size. Turkish Statistical Institute

Turkstat (2020) Population according to province, age and sex, 20072019. Turkish Statistical Institute. http://www.tuik.gov.tr/PreTa blo.do?alt_id=1059. Accessed 19 July 2021

UCLA (2021) Descriptive statistics SPSS annotated output. Statistical Consulting. https://stats.idre.ucla.edu/spss/output/descriptive-stati stics/. Accessed 24 July 2021

Wang P Chen K Zhu S Wang P Zhang H (2020) Severe air pollution events not avoided by reduced anthropogenic activities during COVID-19 outbreak. Resour Conserv Recycl. https://doi.org/10. 1016/j.resconrec.2020.104814

WAQI (2020) World's air pollution: real-time air quality index. Beijing. https://waqi.info/. Accessed 11 July 2021

Wheaton WC, Thompson AK (2020) The geography of COVID-19 growth in the US: counties and metropolitan areas. https://papers. ssrn.com/sol3/papers.cfm?abstract_id=3570540 Accessed 17 July 2021

World Bank Group, Esmap, Vortex, DTU (2021) Global Wind Atlas. https://globalwindatlas.info/area/Turkey/. Accessed 13 July 2021

Wu Y Jing W Liu J Ma Q Yuan J Wang Y et al (2020) Effects of temperature and humidity on the daily new cases and new deaths of COVID-19 in 166 countries. Sci Total Environ. https://doi.org/10. 1016/j.scitotenv.2020.139051

Xie J Zhu Y (2020) Association between ambient temperature and COVID-19 infection in 122 cities from China. Sci Total Environ. https://doi.org/10.1016/j.scitotenv.2020.138201

Zhang Y, Tian H, Zhang Y, Chen Y (2020a) Is the epidemic spread related to GDP? Visualizing the distribution of COVID-19 in Chinese Mainland. http://arxiv.org/abs/2004.04387. Accessed 18 July 2021

Zhang Z Xue T Jin X (2020b) Effects of meteorological conditions and air pollution on COVID-19 transmission: evidence from 219 Chinese cities. Sci Total Environ. https://doi.org/10.1016/j.scito tenv.2020b.140244

Zhang H Liu Y Chen F Mi B Zeng L Pei L (2021) The effect of sociodemographic factors on COVID-19 incidence of 342 cities in China: a geographically weighted regression model analysis. BMC Infect Dis. https://doi.org/10.1186/s12879-021-06128-1

Zhu Y Xie J Huang F Cao L (2020) Association between short-term exposure to air pollution and COVID-19 infection: evidence from China. Sci Total Environ. https://doi.org/10.1016/j.scitotenv.2020. 138704 